\title{
Self-Efficacy Levels and Gender Differentials among Teacher Trainees in Colleges of Education in Botswana
}

\author{
Waitshega Tefo Smitta Moalosi ${ }^{1} \&$ Ntonghanwah Forcheh ${ }^{2}$ \\ ${ }^{1}$ Department of Educational Foundations, University of Botswana, Gaborone, Botswana \\ ${ }^{2}$ Department of Statistics, University of Botswana, Gaborone , Botswana \\ Correspondence: Dr. W. T. S. Moalosi, Department of Educational Foundations, University of Botswana, \\ Gaborone, Botswana. Tel: 267-3-55-4587. E-mail: smitta.moalosi@mopipi.ub.bw
}

Received: November 9, 2014

Accepted: January 30, 2015

Online Published: August 11, 2015

doi:10.5539/jel.v4n3p1

URL: http://dx.doi.org/10.5539/jel.v4n3p1

\begin{abstract}
Teachers with a high sense of efficacy have been found to be more passionate about teaching, ready to accept new ideas and make attempts to use new teaching methods to help students learn. Such teachers have positive teaching behaviors such as patience, commitment, enthusiasm, which in turn lead to positive student outcomes. However, research on teacher efficacy and classroom management is lacking in Botswana. The main aim of this study is to determine the extent of self-efficacy beliefs among final year students in all the teacher training colleges in Botswana, and to determine as to whether there are differences associated with gender, age and college.

A total of 598 pre-service teacher trainees completed the quantitative survey. Self-efficacy was measured using the Long Form version of the Teachers' Sense of Efficacy Scale which comprises of 24 items divided 3 -subscales of 8 items each. The self-efficacy score for each student on each subscale was measured using the average score on the 8-items that make up the scale. Analysis of variance was used to investigate if self-efficacy depended on gender, age and college.

The findings revealed that the level of self-efficacy was moderated among the trainees, averaging around 3.8 on a scale of 1 to 5. Self-efficacy increased with age for each subscale. Females outperformed males with respect to student engagement, but there were no significant gender differences with respect to instructional strategies and classroom management. There were significant differences between the five colleges with respect to each sub-scale, with one particular college having the lowest mean on all subscales, and another having the highest mean on all subscales. Interestingly the colleges that train primary had higher mean scores than those that train and secondary school teachers. However, further investigations revealed some partial confounding between age and school. The findings suggest that more efforts should be put into empowering pre-service teachers to develop self-confidence in class room management, instructional strategies and student engagement.
\end{abstract}

Keywords: teacher, pre-service, self-efficacy, TSES, college of education, Botswana, analysis of variance

\section{Introduction}

\subsection{Overview}

During the 9th National Development Plan, the government of Botswana undertook "to offer equitable lifelong education and training that is relevant and responsive to the rapid technological development and changing socio-economic environment, and that produces knowledgeable, skilled, enterprising and independent individuals" (NDP 9, 2009, p. 268). In addition, the government committed itself to improving the quality and training of teachers as part of its strategy to achieve this goal (Vision, 2016, p. 30). As a consequence, the ministry of education continues to get the lion share of the national budget each year. However, the expected improvements in student performance have not been realized as pass rates in primary and secondary examinations have stagnated. In 2014, concerns regarding failing standards were so serious that a committee of the cabinet was sent around schools to determine first hand, the possible causes. The report from these visits has not been made public. Furthermore, little research appears to have been conducted to establish the quality and training of the teachers involved and the contribution of teacher's factors in the Botswana education system including poor performances of students at primary, junior and secondary schools. This state of affairs calls for 
interrogations on the strategies to be put in place to respond to challenges and weakness in the education system. The question of teacher self-efficacy is core, as it entails aiming to deliver quality education; particularly in engaging students in learning, using different methods of teaching and managing unruly behaviors in the learning environments.

\subsection{Teacher Self-Efficacy Belief}

Teacher self-efficacy refers to a teacher's "judgment of his/her capabilities to bring about the desired outcomes of student engagement and learning, even among students who may be difficult or unmotivated" (Tschannen-Moran \& Woolfolk Hoy, 2001, p. 783). Teachers' efficacious beliefs are related to the ability for the teacher to devote their time to professional instruction and to be accountable in educating all students including those with learning disabilities (Dembo \& Gibson, 1985). Perceived self-efficacy, according to Bandura (1997), includes "beliefs in one's capabilities to organize and execute the courses of action required to produce given attainments" (p. 3).

In this study we propose the use of self-efficacy beliefs among pre-service teachers as a measure of the quality and training of teachers in Botswana. This is justifiable because teacher efficacy has been found to be more consistently correlate with student behavior and their learning outcomes than any other teacher characteristic (Tschannen-Moran \& Woolfolk Hoy, 2001).

In an extensive review of the literature regarding teacher efficacy, Haverback and Parault (2008) found that self-efficacy beliefs were positively associated with willingness to embrace innovative teaching techniques, job satisfaction among teachers and desire to stay in the job, and negatively associated with professional burnout. Other researchers such as Henson, Kogan and Vachar Haase (2001); Shaughnessy (2004); Tschannen-Moran and Woolfolk Hoy (1998) and Tschannen-Moran and Woolfolk Hoy (2001) have found positive relationships between teachers' sense of efficacy and good teaching behaviors, patience, commitment, enthusiasm and instructional actions taking place in the classroom settings.

Teachers who possess high efficacious beliefs are more likely to accept new ideas, to use new teaching techniques and are passionate about teaching than teachers with lower efficacious beliefs (Allinder, 1994; Bandura, 1993; Guskey, 1988; Ross, 1992; Stein \& Wang, 1988). Teachers with a high sense of efficacy tend to be more passionate about teaching (Allinder, 1994; Bandura, 1993). They accept new ideas and make attempts to use new teaching methods to help students learn (Guskey, 1988; Stein \&Wang, 1988).

Pre-service teachers have been thought of as teachers who ought to have stronger efficacious beliefs to function in the education field (Mulholland \& Wallace, 2001). Hence they offer an excellent entry point for studying teacher efficacy levels, because unlike regular teachers, they have not yet experienced the reality of the classroom, which as observed by Harverback and Parault (2008), "may take away some of the idealism with which (they) enter the classroom". Woolfolk Hoy, and Burke-Spero (2006) found that the level of efficacy among pre-service teachers increased with training, then decreased during their first year of teaching (p. 727).

\subsection{Theoretical Framework}

In Social Cognitive Theory, beliefs act as mediators between knowledge and behaviors while connecting to environmental situations. Hence Bandura argued that self-efficacy beliefs are vital to "human agency" and to an individual's capability to do something (Bandura, 1977; Dellinger, Bobbet, Olivier, \& Ellet, 2008).

Beliefs are vital because they can enable an individual to be focused on what they are doing. Pajares (1992) asserted, "beliefs are best indicators of the decisions individuals make throughout their lives" (p. 307). Therefore, beliefs can also influence teachers to make decisions in relation to their work, especially on their own abilities to influence student learning and performance. They can plan; prepare their instructional methods of teaching that effectively impact students learning during their career as teachers.

Bandura (1977) introduced the concept of self-efficacy beliefs as an assessment of one's capabilities to attain a desired level of performance in a given endeavor. Therefore, an individual's convictions that he/she has the ability to do what is required in preparing and completing assignments in an excellent way enhances their performance in a classroom setting (Dellinger et al., 2008).

Studies on the area of teacher efficacy, has led researchers to conclude that even if teachers attend workshops and are exposed to additional teaching methods, they will still be resistant to change. On the other hand, efficacy beliefs have an effect on thinking, feelings and motivation, and behavior (Bandura, 1993). Therefore, teachers with high level of efficacy can develop positive attitude toward their work, in general, have control over 
disruptive behavior and confidence in how to handle those behaviors and have a positive impact on students' undesirable behaviors.

\section{Statement of the Problem}

Historically in Botswana, teacher training on content mastery has been construed to be the basis of teacher efficacy. However, this has not resulted in the improvement of delivery and to the efficient response to quality education. Research on teacher efficacy is lacking in Botswana. While examining teacher efficacy in the University of Botswana Library's Botswana Collection section, the authors did not find any work related to teacher efficacy. Hence, teacher efficacy needs to be investigated further. Dibapile (2012) researched Botswana junior secondary school teachers' responses to the three aspects of Teachers' Sense of Efficacy scale, (TSES) Efficacy in Student Engagement, Efficacy in Instructional Strategies and Efficacy in Classroom management. Her study findings showed that teachers had high teacher efficacy in Student Engagement only. The above mentioned researchers did not investigate pre-service teacher sense of efficacy beliefs. But, they focused on in-service teacher. Therefore, the present study researched on pre-service teachers efficacy beliefs. Investigating pre-service efficacious beliefs is vital. Because it is not known if the teacher trainees believes in themselves if they can impact learning or have opted for teaching as a career because of job related benefits.

Magogwe and Oliver (2007) researched "the relationship between language and learning strategies, proficiency, and self-efficacy beliefs of students in Botswana" and found that the students used average self-efficacy beliefs in "their learning of the English language although not consistently so" (p. 350). Brandon (2000) investigated gender differences' effect on self-efficacy of prospective teachers in Botswana's four primary teacher colleges. Her study focused on "male and female students' beliefs about their ability to perform specific teaching competences before going into the classroom" (p. 37).

The instrument used in Brandon's study was Likert-type and included 16 items that measured students' behaviors. Brandon found that female pre-service teachers had lower self-efficacy in "specific teaching competences" than males prior to going into the field. Both these studies analyzed students' self-efficacy, leaving pre-service teachers' sense of efficacy beliefs under researched. The results of the study will benefit teacher educators, the ministry of education, and stake holders and will recommend ways in which Botswana's teacher education can be improved. Low teacher efficacy has negative influence in learning.

This study employed a comparative study of the levels of self- efficacy and differentials in efficacious beliefs among pre-service teachers using three aspects of teacher efficacy; Efficacy in Student Engagement, Instructional Strategies and Classroom Management. These subscales are adopted from the teachers' sense of efficacy (TSES Long Form) instrument.

\section{Rationale}

Entry requirements into teachers' training colleges in Botswana are not as stringent as entry requirements into the university. Furthermore, on graduation, teacher trainees are assured of jobs, are offered accommodation in schools at highly subsidized rentals, can take school holidays and have other benefits related to the profession that may not be available to employees in other sectors. Some school leavers may choose to train as teachers not because they believe in their own abilities to impact knowledge and influence student learning, but either as a last resort, or because of the attractive package on graduation.

Self-efficacy has been conceptualized by Bandura (1993) as perceived operational capability concerned with the belief in what one can do with whatever resources one can master. Therefore, teachers are likely to require more mastery experiences during training in order to create a high sense of efficacy compared with highly qualified trainees who are driven by a sense of impacting knowledge to learners.

The decline in student performances in secondary school examinations in the recent years suggest that some teachers may not be engaging students in learning, do not manage the classrooms effectively as well as not using appropriate and innovative instructional methods in teaching. Hence an investigation of teacher efficacy among pre-service teachers in the different colleges is important. Because the results of the research carried with pre-service teachers will raise awareness of teacher educators on the strategies they can implement; to assist pre-service teachers to belief in themselves in regard to be effective teachers who can have a positive impact on students' learning. 


\section{Research Questions}

1) How do pre-service teachers in Botswana rate themselves in relation to the three subscales of Teachers' Sense of Efficacy scale, (TSES) Efficacy in Student Engagement, Efficacy in Instructional Strategies and Efficacy in Classroom Management?

2) Are there any gender differences in pre-service teachers' self-ratings?

3) Do younger and older teachers rate themselves equally on each subscale?

4) Are there differences in student ratings between colleges? If so which colleges have the best and the worst self-ratings?

\section{Method}

Quantitative survey was employed as a method of collecting data from pre-service teachers in Botswana colleges of education. The questionnaires were administered to pre-service teachers in the five colleges of education in Botswana that train secondary school teachers (Molepolole and Tonota) and primary (Tlokweng, Serowe, and Francistown) colleges of education respectively. The Teachers' Sense of Efficacy Scale (TSES), Long Form Instrument, with 24 items, comprising of the three subscales, Efficacy in Student Engagement, Efficacy in Instructional Strategies and Efficacy in Classroom Management was used in the study to measure the efficacious beliefs of pre service teachers.

The target population consisted of all students at each college who were left with one month to complete their training. There were generally less than 200 students in each college, and hence the aim was to administer questionnaire to all trainees. However, only trainees who were available on the day of data collection or the subsequent follow up day were included. The participants completed the questionnaire in the presence of the research assistance that provided them the opportunity to seek any clarifications. In Molepolole and Tonota multiple follow-ups were made after the planned day for data collection. Hence in both colleges, 162 out of a possible 183 trainees responded. The response rate in Francistown was lowest because there was no opportunity to make follow-ups. For Serowe and Tlokweng the questionnaires were distributed to all present at the general assembly on the planned day. The sample comprised of those who completed and returned their questionnaires on that day. There was no opportunity for follow-ups of non-respondents.

The questionnaire comprised of the Teachers' Sense of Efficacy Scale (TSES), Long Form Instrument, with 24 items. Each of the 24 questionnaire items used to measure self-efficacy was scored on a Likert type scale that measured the extent to which the teacher felt they could influence specific outcomes. The response options were: 1-Nothing (i.e. cannot influence student behavior); 2-Very little; 3-Some influence; 4 -Quite a bit; 5-A great deal. The average score of each respondent on a given subscale (Efficacy in Student Engagement, Efficacy in Instructional Strategies and Efficacy in Classroom Management) was used as a measure of self-efficacy belief on that subscale. Information on the following background variables was also collected: gender, age, highest education prior to entering the college, and teaching experience.

\section{Data Analysis}

In order to investigate question 1, each TSES item was recoded from 5 to 3 categories representing those who belief that (1) there is little or nothing they can do on the item (no influence), (2) they have some influence or quite a bit of influence (some influence) and (3) they have a great deal of influence. If a high percentage of respondents stated that they have a great deal of influence on a particular item, then the item as classified as a positive item, whereas if only a small percentage believe that they have high influence, then the item as classified as negative. The items within each subscale were then ranked from the most positive to the most negative.

The analysis of variance method was used to investigate questions 2-4, with the dependent variable being the mean score for each subscale. The following ANOVA model was fitted in order to investigate questions 2 and 3 :

$$
y_{i j k}=\mu+\alpha_{i}+\beta_{j}+(\alpha \beta)_{i j}+\varepsilon_{i j k}
$$

where $\alpha, \beta \&(\alpha \beta)$ are used to measure respectively, the effects of sex, age and the possible interaction between them while $\varepsilon$ represents the random error. The significance of sex, age and/or their interaction was tested by constructing an analysis of variance table. The p-value corresponding to each factor was used to judge the degree of statistical significant of the factor. Profile plots were used to examine the nature of the interaction term (if present). Levene's test for equality variances was used to verify the reliability of the assumption homogeneity of variances. 


\section{Question 4:}

In order to investigate question 4, a one way analysis of variance was fitted, and used to test the null hypothesis that the mean score in all the colleges were equal. The test also include Levene's test for equality of variances. Where differences between colleges where found for any subscale, the colleges were ranked by the mean score. It was not possible to include gender and age differences because of the imbalance in ratio of men to women as well as differences in age cohorts in different colleges. For example, in some of the colleges, there were no trainees in some of the age groups.

The number of categories in each self-efficacy subscale was reduced from 5 to 3 for ease of interpretation of findings. The new category 1 was obtained by combining those who said that there is nothing they can do to influence students with those who said there is very little they can do. Respondents who said they had some influence and those who said that they had quite a bit of influence were also combined and the last category, representing those think they had a great deal of influence was kept distinct.

\section{Findings}

\subsection{Preliminary Results}

The sample consisted of 589 teacher-trainees with 162 from each of Molepolole (MCE) and Tonota (TCE) colleges of education and 109, 86 and 79 trainees from Serowe, Tlokweng and Francistown colleges of education respectively. The relative numbers of respondents by sex and college are shown in Figure 1.

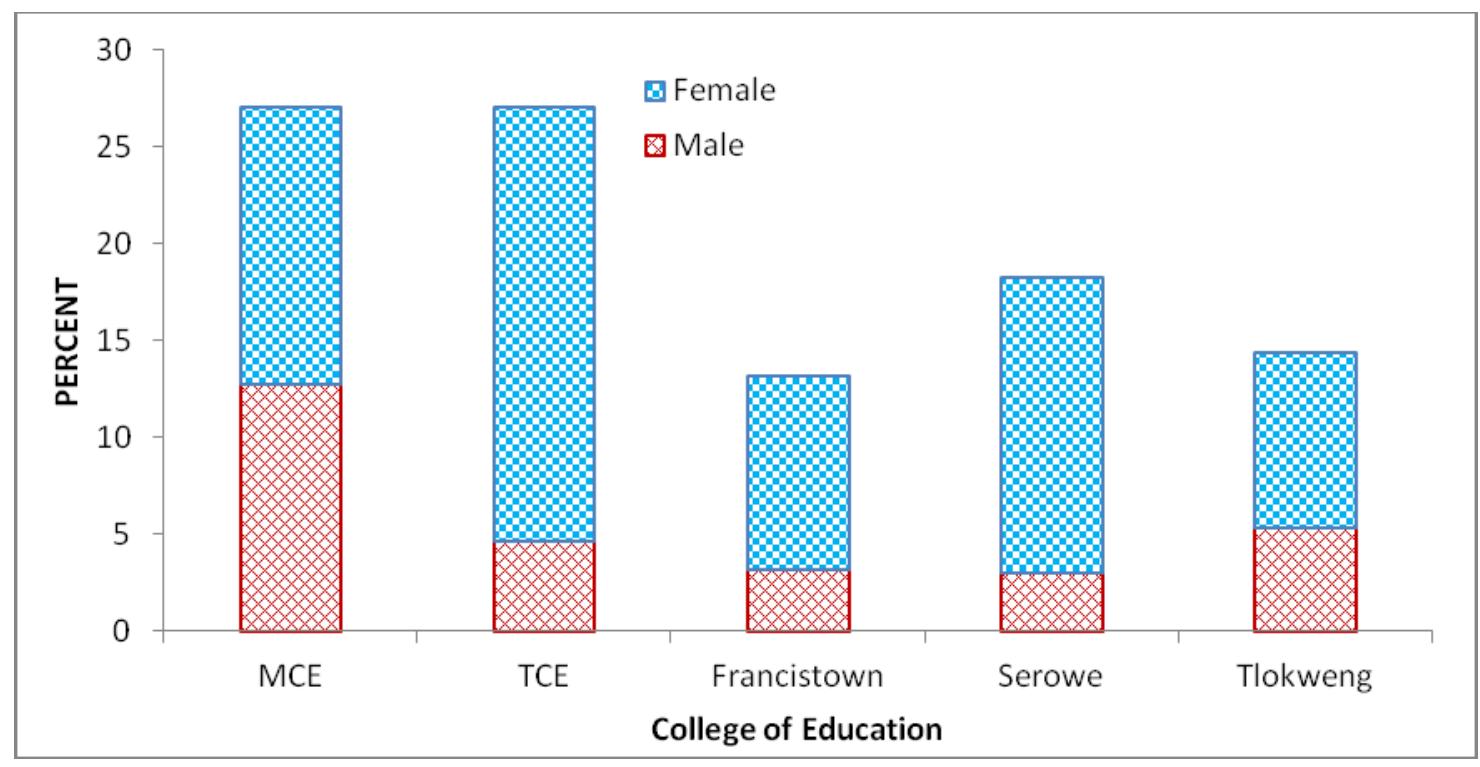

Figure 1. Distribution of respondents by college and sex

There were relatively more female trainees than males in all colleges, with the largest differential being in Tonota, Serowe, and Molepolole Colleges of Education were only approximately $17 \%$ of trainees were male. Only in MCE was the proportion of males (47\%) comparable to that of females. The age distribution of the trainees also differed significantly between the colleges.

\section{Question 1:}

How do pre-service teachers in Botswana rate themselves in relation to the three subscales of Teachers' Sense of Efficacy scale, (TSES) Efficacy in Student Engagement, Efficacy in Instructional Strategies and Efficacy in Classroom Management?

For this section, respondents who said there is nothing or very little they can do were combined while those who had some influence or quite a bit of influence were also combine for ease of interpretation of findings. The summaries in Table 1 show the distribution of respondents in each item within each subscale.

With respect to the student engagement subscale, trainees were generally confident on ability to motivate students, to get students believe they can do well in school work and to value education with over $40 \%$ of 
trainees saying they have a great deal of influence in each of the items and under 105 indicating that they have no influence.

Table 1. Trainee teachers self-rating of ability to influence various aspects of student engagement, instructional strategy and classroom management

\begin{tabular}{|c|c|c|c|c|c|}
\hline & $\begin{array}{l}\text { Sub-Scale and sub items } \\
\text { Student Engagement sub-item }\end{array}$ & $\begin{array}{l}\text { No } \\
\text { influence }\end{array}$ & $\begin{array}{l}\text { Some } \\
\text { influence }\end{array}$ & $\begin{array}{l}\text { A great } \\
\text { deal of } \\
\text { influence }\end{array}$ & Total \\
\hline 1 & $\begin{array}{l}\text { how much can you do to motivate students who show low } \\
\text { interest in school work }\end{array}$ & 6.4 & 48.2 & 45.5 & 100.0 \\
\hline 2 & $\begin{array}{l}\text { how much can you do to get students to believe they can do } \\
\text { well in school work }\end{array}$ & 5.5 & 50.2 & 44.3 & 100.0 \\
\hline 3 & how much can you do to help your students value education & 5.7 & 52.8 & 41.5 & 100.0 \\
\hline 4 & how much can you do to foster students creativity & 7.9 & 60.8 & 31.3 & 100.0 \\
\hline 5 & $\begin{array}{l}\text { how much can you do to improve the understanding of student } \\
\text { who is failing }\end{array}$ & 7.4 & 62.0 & 30.6 & 100.0 \\
\hline 6 & how much can you do to help your students think critically & 8.2 & 63.2 & 28.6 & 100.0 \\
\hline 7 & $\begin{array}{l}\text { how much can you assist families in helping their children to } \\
\text { do well in school }\end{array}$ & 16.4 & 55.9 & 27.8 & 100.0 \\
\hline \multirow[t]{2}{*}{8} & $\begin{array}{l}\text { how much can you do to get through to the most difficult } \\
\text { students }\end{array}$ & 18.6 & 57.0 & 24.4 & 100.0 \\
\hline & Instructional Strategy sub-item & & & & \\
\hline 1 & $\begin{array}{l}\text { how well can you provide appropriate strategies for very } \\
\text { capable students }\end{array}$ & 8.9 & 51.0 & 40.1 & 100.0 \\
\hline 2 & $\begin{array}{l}\text { to what extent can you provide an alternative explanation or } \\
\text { example when students are confused }\end{array}$ & 8.0 & 55.2 & 36.8 & 100.0 \\
\hline 3 & how much can you use a variety of assessment strategies & 11.4 & 56.4 & 32.3 & 100.0 \\
\hline 4 & $\begin{array}{l}\text { how well can you implement alternative strategies in your } \\
\text { classroom }\end{array}$ & 7.4 & 61.5 & 31.1 & 100.0 \\
\hline 5 & $\begin{array}{l}\text { how well can you respond to difficult questions from your } \\
\text { students }\end{array}$ & 8.0 & 63.3 & 28.6 & 100.0 \\
\hline 6 & $\begin{array}{l}\text { how much can you gauge student comprehension of what you } \\
\text { have taught }\end{array}$ & 8.4 & 63.0 & 28.6 & 100.0 \\
\hline 7 & to what extent can craft good question for your students & 7.5 & 65.4 & 27.1 & 100.0 \\
\hline \multirow[t]{2}{*}{8} & $\begin{array}{l}\text { how much can you do to adjust your lessons to the proper level } \\
\text { for individual student }\end{array}$ & 10.2 & 64.0 & 25.8 & 100.0 \\
\hline & Classroom management sub-item & & & & \\
\hline 7 & $\begin{array}{l}\text { how much can you do to control disruptive behavior in the } \\
\text { classroom }\end{array}$ & 7.4 & 46.2 & 46.5 & 100.0 \\
\hline 1 & how much can you do to get children to follow classroom rules & 8.4 & 50.3 & 41.4 & 100.0 \\
\hline 4 & $\begin{array}{l}\text { how much can you do to calm a student who is disruptive or } \\
\text { noisy }\end{array}$ & 10.0 & 56.4 & 33.6 & 100.0 \\
\hline 3 & $\begin{array}{l}\text { how well can you keep a few problem students from ruining an } \\
\text { entire lesson }\end{array}$ & 7.2 & 60.0 & 32.8 & 100.0 \\
\hline
\end{tabular}


5 to what extent can you make your expectation clear about students behavior

10.0

10.9 how well can you establish
with each group of students

6 how well can you establish routine to keep class smoothly running

$\begin{array}{llll}10.0 & 58.9 & 31.1 & 100.0 \\ 10.9 & 60.7 & 28.4 & 100.0 \\ 9.4 & 63.2 & 27.4 & 100.0 \\ 16.7 & 63.9 & 19.4 & 100.0\end{array}$

On the opposite end of this, trainees were least confident on how much they can get through the most difficult students and in assisting families in helping their children to do well in school. In each under $30 \%$ of trainees felt that they could do a great deal while more than $15 \%$ felt that there is nothing that they could do. Another area of difficulty to the trainee teachers is how much they can do to help your think critically.

The percentage of students who belief that they have a great deal of influence in various instructional strategy items was generally under $40 \%$ except with respect to providing appropriate strategies for very capable students. Just over a third of the teacher trainees believe that they are very capable of providing an alternative explanation for example when students were confused. Although this is the second highest ranked among the 8 items in this scale, the percent is rather low, given the importance of using alternative examples to clarify concepts. The trainees show least self-beliefs with respect to adjusting lessons to the proper level for individual student, crafting good question for the students and using a variety of assessment strategies.

With respect to class room management, the leading items in which trainees felt they could have a great deal of were controlling disruptive behavior in the classroom and getting children to follow classroom rules. In both cases over $40 \%$ felt very confident in their abilities to influence student behaviors, and less than $10 \%$ felt that they had no ability. On the negative side, fewer than $20 \%$ of staff felt very confident in their ability to deal with very defiant students and almost $17 \%$ felt that they had no ability at all. Trainees were also generally unsure about their abilities to establish a classroom management system with each group of students or to establish routine to keep class running smoothly.

\section{Question 2 and 3:}

Are there any gender differences in pre-service teachers' self-ratings and do younger and older teachers rate themselves equally on each subscale?

The full ANOVA model with interaction was fitted for each subscale to determine if there were any age and gender differentials. Levene's test for equality of variances was used to determine if the within groups variability was equal. ANOVA tables and mean plots were used to determine the extent and nature of differences between the groups. The within group means and their standard errors for each subscale by gender and age group are shown in Table 2.

\subsection{Age-Gender Differences in Student Engagement}

The F-statistic for Levene's test for equality of variances was 1.72 on $(2,590)$ degrees of freedom hence confirming that the within groups variability was equal $(p=0.101)$. The ANOVA table reveals significant differences due to sex $(p=0.011)$ and age group $(p<0.01)$, but that there was no significant interaction between sex an age $(p=0.493)$. The mean plot revealed that mean student engagement scores increase linearly with age for both males and females, with female scores generally higher than male scores. Except for age group 25-29 in which male and females had the same mean score and age group 34-44 who had a lower mean score than group 25-29.

The pairwise comparisons showed that respondents aged 20-24 performed significantly worse than all older pre-service teacher trainees, while those aged $45+$ scored significantly better than all younger age groups. The difference between those aged 25-29 and those 30-34 was not statistically significant $(\mathrm{p}=0.397)$. 

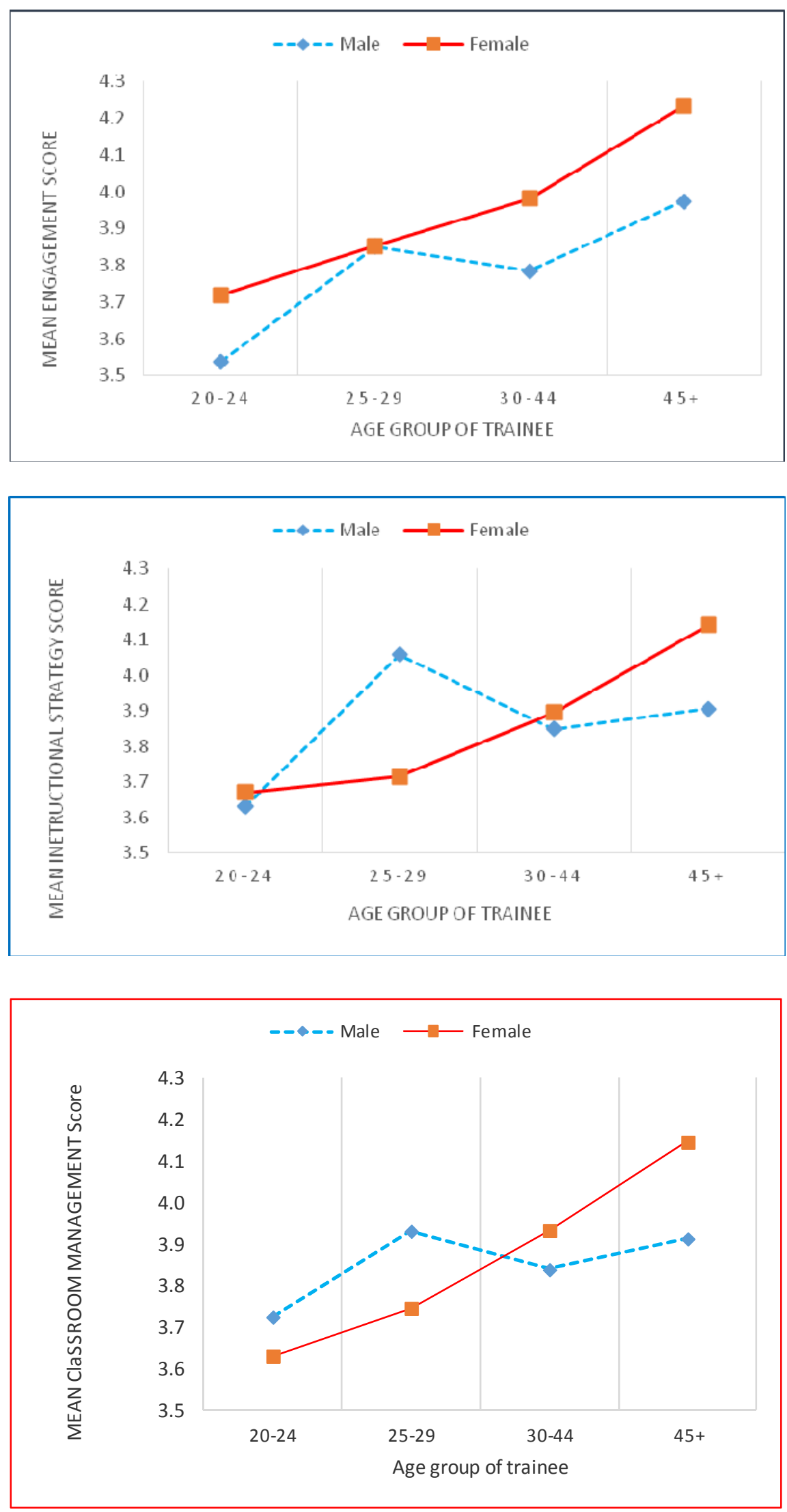

Figure 2. Average scores in class management, instructional strategies and class room management by sex and age of a trainee. 


\subsection{Age-Gender Differences in Instructional Strategies}

The age and gender differences were significant. The results revealed that the within group variances were not significantly different $(\mathrm{p}=0.142)$. The analysis of variance showed that mean score in instructional strategies for males (3.83) was almost identical to that for females (3.81). However, a significant interaction $(\mathrm{p}=0.021)$ was found between sex and age.

Table 2. Average scores in class management, instructional strategies and class room management by sex and age of a trainee

\begin{tabular}{lllllllll}
\hline & \multicolumn{3}{l}{ Classroom } \\
\multicolumn{3}{l}{ Management } & \multicolumn{2}{l}{ Instructional Strategies } & Classroom management \\
\hline Sex & Age & Mean & Std. Error & Mean & Std. Error & Mean & Std. Error & $\mathrm{N}$ \\
& $20-24$ & 3.72 & 0.092 & 3.63 & 0.087 & 3.54 & 0.087 & 62 \\
& $25-29$ & 3.93 & 0.094 & 4.06 & 0.095 & 3.85 & 0.075 & 47 \\
Male & $30-44$ & 3.84 & 0.097 & 3.85 & 0.085 & 3.78 & 0.078 & 44 \\
& $45+$ & 3.91 & 0.117 & 3.91 & 0.122 & 3.98 & 0.136 & 20 \\
& All males & 3.83 & 0.050 & 3.83 & 0.049 & 3.74 & 0.046 & 173 \\
& $20-24$ & 3.63 & 0.055 & 3.67 & 0.056 & 3.72 & 0.052 & 166 \\
& $25-29$ & 3.74 & 0.079 & 3.72 & 0.080 & 3.85 & 0.074 & 96 \\
Female & $30-44$ & 3.93 & 0.062 & 3.90 & 0.071 & 3.98 & 0.063 & 91 \\
& $45+$ & 4.15 & 0.069 & 4.14 & 0.070 & 4.23 & 0.073 & 72 \\
& All Females & 3.81 & 0.034 & 3.81 & 0.035 & 3.89 & 0.033 & 425 \\
& $20-24$ & 3.66 & 0.047 & 3.66 & 0.047 & 3.67 & 0.045 & 228 \\
Both & $25-29$ & 3.81 & 0.062 & 3.83 & 0.063 & 3.85 & 0.055 & 143 \\
& $30-44$ & 3.90 & 0.052 & 3.88 & 0.055 & 3.92 & 0.050 & 135 \\
& $45+$ & 4.10 & 0.060 & 4.09 & 0.061 & 4.18 & 0.065 & 92 \\
& All Trainees & 3.81 & 0.028 & 3.82 & 0.029 & 3.85 & 0.027 & 598 \\
\hline
\end{tabular}

For females, mean score in instructional strategies increase steadily with age ranging from 3.67 for those aged 20-24 to 4.14 for those aged 45+. The youngest pre-service teachers also had the lowest mean score of 3.61 followed by those aged 30-44 with a mean of 3.85 with those aged 25-29 having the highest mean score of 4.06. The difference between mean scores in instructional strategies for males aged 20-24, 30-44 and those aged 45+ was small.

\subsection{Age-Gender Differences in Classroom Management}

With respect to class room management, there was no difference $(\mathrm{p}=0.856)$ between the mean score for males (3.85) and that for females (3.86). Similarly the interaction between sex and age was not significant $(\mathrm{p}=0.140)$. As with other subscales, the mean score in class room management increased significantly with age $(\mathrm{p}=0.002)$, especially for female trainees were the increase was linear for all subscales.

Interestingly, the younger males scored higher than their corresponding female counterparts, while the older male trainees' score lower than their corresponding female counterparts. However, the differences do not appear to be statistically significant.

\subsection{School Differentials in Instructional Strategies}

The full ANOVA model involving school, sex and the interaction between them was fitted to investigate if there are any within school differentials between males and female trainees. The interaction was however, not statistically significant $(\mathrm{p}=0.475)$. The school factor was found to be highly significant. 


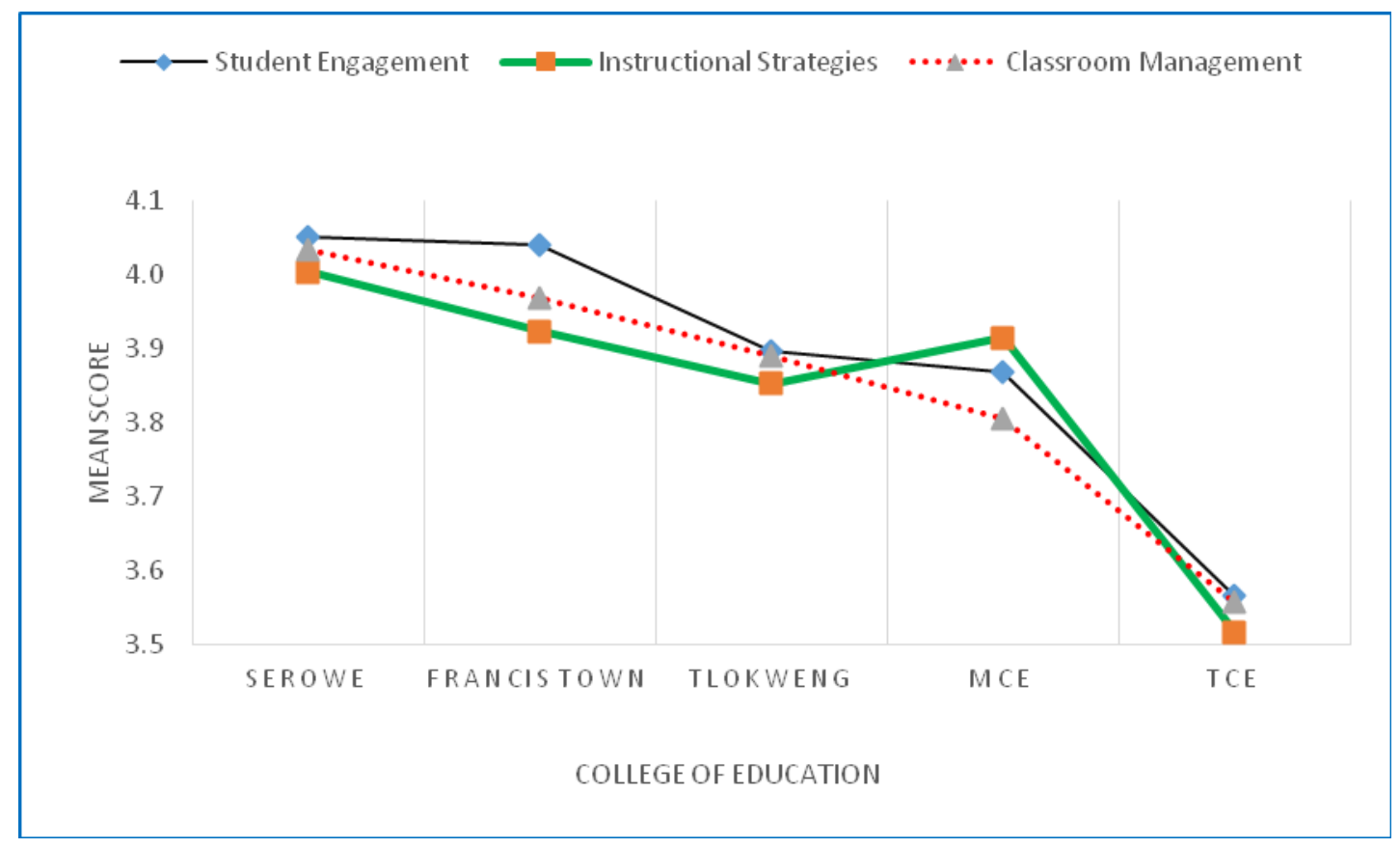

Figure 3. Mean ratings of self-efficacy by college of education

As shown in Figure 3, Tonota College of Education (TCE) records the lowest mean score on all 3 subscales, while Serowe College records the highest mean scores followed by Francistown. Self-ratings at Molepolole College of Education (MCE) are about the same as those in Tlokweng College. Preliminary analysis revealed that Serowe College has the most diverse students with respect to age. This illustrates that there are indeed real significant inter school effects in trainee teachers self-ratings of a sense teacher efficacy which need to be further investigate.

The comparing ratings in the 3-subscale within colleges, we observe from the graph that the differences were small. In fact correlation analysis revealed that the correlation between student engagement score and instructional strategies was 0.793 , and between student engagement score and classroom management was 0.747 while that between classroom management score and instructional strategies was 0.786 . Furthermore these correlation coefficients were highly significant with $\mathrm{p}<0.001$ in all cases.

Paired samples test revealed that overall, differences between the mean scores student engagement and instructional strategies, student engagement and classroom management and between instructional strategies and class room management were respectively 0.028 (SEM=0.020), $0.038 \quad(\mathrm{SEM}=0.021)$ and $0.010(\mathrm{SEM}=0.020)$. Hence none of these differences was statistically significant at the $5 \%$ level.

Adjusting for colleges, the paired comparisons revealed that at MCE, mean instructional strategies scores were significantly higher than mean scores in classroom management $(\mathrm{p}=0.013)$. At Francistown, mean scores in student engagement were significantly higher than those in Instructional Strategies $(\mathrm{p}=0.008)$. None of the other paired wise comparisons within schools showed statistically significant differences at $10 \%$ level of significance.

The results of Tonota College are a cause for concern. Trainees from this college and from Molepolole college go on to teach at the secondary school level while those from the other three colleges go on to teach at primary level. The main entry requirements into the colleges are a minimum of Botswana General Certificate of Secondary Education (BGCSE) Ordinary level) or its equivalent with credits in at least three subjects, one of which should be English. For the trainees returning to teach in the same secondary schools from which they only recently graduated as low achievers, it is not be surprising that they do not have a high sense of self-efficacy. By contrast, trainees from Serowe, Francistown and Tlokweng have spent five years in secondary since completing the primary schools and are now equipped with 3-year training as teachers, and hence will have a higher sense of efficacy than trainees at MCE and TCE.

The findings in this study revealed that the strongest differences were between the very young teachers and the oldest ones. Furthermore, trainees at MCE and TCE were all under 40 years of age and mainly under 35 years of age, while all students in Francistown were over 34 years old and in Serowe and Tlokweng, most trainees were 
either young (under 30 years) or old (40+). Therefore, it is difficult to fully separate age effects from and college difference nevertheless this only reinforces the possibility that the relatively low efficacy scores in TCE indicate a sense of lack of self-confidence among these trainees resulting from their inadequate basic academic qualifications.

\section{Discussion}

The results of the present study have interesting findings. Males in Molepolole College of education aged between 25-29 shows a higher teacher efficacy in all the three subscales. Females in the same college and ages are worst performers. The results are interesting because in Botswana teaching has been perceived as a female job, but males are now showing interest in teaching profession. Pre-service teachers in Serowe college aged 20-24 rated themselves high in relation to student engagement. MCE, TCE and FTC aged 25-29 doing better also in Student engagement. Young adults of ages 20-24 at Tlokweng College also do well in student engagement and worst performers in student engagement in Tlokweng are from ages 24-29.

Males in the present study, aged 25-29 are doing well in classroom management and in other subscales as well. There is a shift in teacher efficacy research, past research of teacher efficacy reported, females having a higher teacher efficacy than males Anderson, Greene, \& Lowen Evans \& Tribble, Raudenbush (as cited in Anderson, 2011). Ross, Cousins, and Gadalla (1996) "argued that, this is so because teaching is viewed as a female occupation" (p. 389).

The results of the present study contradict the mentioned above research evidence, as the present findings show younger males having a high teacher efficacy than females (Table 2). According to Social Cognitive theory males in the present study possess perceived teacher self-efficacy, whereby, as teachers they believe that they can influence students' behavior and academic achievement. The results also show older students in Serowe College displaying a higher teacher efficacy. Older females in Tlokweng College responded well with regard to classroom management.

\section{Conclusion}

Teachers with a high sense of efficacy are needed in the teaching profession, because they can have a positive impact in students' learning as they contribute to quality education. The findings of the present study reported, that pre-service teachers in the five colleges of Botswana differed in their teacher efficacy beliefs. In relation to how pre-service teachers of the five colleges rated themselves in regard to the three subscales of the Teachers' Sense of Efficacy scales; Serowe College of Education pre-service teachers have higher teacher efficacy beliefs in all the three subscales (see Research question 1).

Younger males had higher efficacy beliefs in classroom management than females in all the five colleges. Gender differences and age in all the subscales did not bear fruitful results some colleges did not have trainees of the same age group. Also, there were more females than males in all the five colleges. What is interesting about the results is, in the three mentioned above subscales efficacy beliefs increased with age. It shows that the more trainees get older they acquire more responsibilities in the work place.

MCE and FTC did well in instructional Strategies and FTC, Tlokweng and MCE held high efficacious believes in classroom management. In all the colleges, in relation to student engagement over $40 \%$ of the trainees believed they can engage students in learning. Those who were confident in using different strategies of teaching were under $30 \%$. Managing classroom behaviors is not easy, but over $40 \%$ of the trainees believed they have a positive impact on students' behaviors. Tonota College of Education scored low in all the three sub-scales implying that the pre-service teachers have a low teacher efficacy. Attention need to be paid to trainees who do not have confidence in engaging students in learning, using different teaching methods as well as managing disruptive behaviors in the learning settings.

Teacher efficacy research is lacking in Botswana and future researchers in teacher efficacy construct can investigate further on the following areas: qualitative studies, longitudinal, observational, case studies and action research. The present study recommends in the following:

Teacher efficacy research is needed in institutions that train teachers in Botswana.

- Curriculum can add more strategies that promote the development of teacher efficacy beliefs in relation to SE, IS \& CM.

- The University of Botswana should allocate more funds for research in Educational Foundations department.

- Instruments to measure teacher efficacy for Botswana/Africa teachers is still vital. 
- The Ministry of Education and Skills Development in Botswana should add more teacher certification programs.

\section{References}

Anderson, L. B. (2011). Teacher diversity: Do male and female teachers have a different self-efficacy and job satisfaction (pp. 7-10). Paper presented for the 33rd EGPA conference in Bucharest.

Adedoyin, O. O. (2012). Factor-analytic study of teachers' perceptions on self-efficacy in Botswana junior secondary schools: Implications for educational quality. European Journal of Educational Studies, 2(2), 139-155.

Allinder, R. M. (1994). The relationship between efficacy and the instructional practices of special education teachers and consultants. Teacher Education and Special Education, 17, 86-95. http://dx.doi.org/10.1177/088840649401700203

Bandura, A. (1977). Self-efficacy: Toward a unifying theory of behavioral change. Psychology Review, 84(2), 479-507. http://dx.doi.org/10.1037/0033-295X.84.2.191

Bandura, A. (1993). Perceived self-efficacy in cognitive development and functioning. Educational Psychologist, 28(2), 117-148. http://dx.doi.org/10.1207/s15326985ep2802_3

Brandon, D. (2000). Self-efficacy: Gender differences of prospective teachers in Botswana. Research in Education, 64, 36-42. http://dx.doi.org/10.7227/RIE.64.4

Dellinger, A. M., Bobbet, J. J., Olivier, D. F., \& Ellet, C. D. (2008). Measuring teachers' self-efficacy beliefs: Development and use of the TEBS-Self. Teaching and Teacher Education, 24, 751-766. http://dx.doi.org/10.1016/j.tate.2007.02.010

Dembo, M. H., \& Gibson, S. (1985). Teachers' sense of efficacy: An important factor in school improvement. The Elementary School Journal, 86, 173-184. http://dx.doi.org/10.1086/461441

Dibapile, W. T. S. (2012). Teacher efficacy and classroom management among Botswana junior secondary school teachers (Published doctoral dissertation). University of Tennessee, Knoxville, USA.

Guskey, T. R. (1988). Teacher efficacy, self-concept, and attitudes toward the implementation of instructional innovation. Teaching and Teacher Education, 4(1), 63-69. http://dx.doi.org/10.1016/0742-051X(88)90025-X

Haverback, H. R., \& Parault, S. J. (2008). Pre-service reading teacher efficacy and tutoring: A review. Educational Psychology Review, 20(3), 237-255. http://dx.doi.org/10.1007/s10648-008-9077-4

Henson, R. K., Kogan, L. R., \& Vacha-Haase, T. (2001). A reliability generalization study of the teacher efficacy scale and related instruments. Educational and Psychological Measurement, 61(3), 404-420. http://dx.doi.org/10.1177/00131640121971284

Long Term Vision for Botswana: Towards prosperity for all. (2016). Botswana Government Printer, Gaborone.

Magogwe, J. M., \& Oliver, R. (2007). The relationship between language learning strategies, proficiency, age and self-efficacy beliefs: A study of language learners in Botswana. System, 35, 338-352. http://dx.doi.org/10.1016/j.system.2007.01.003

Mulholland, J., \& Wallace, J. (2001). Teacher induction and elementary science teaching: Enhancing self-efficacy. Teaching and Teacher Education, 17, 243-261.http://dx.doi.org/10.1016/S0742-051X(00)00054-8

National Development Plan 9. (2009). Long term vision for Botswana: Ministry of finance development and planning. Gaborone: Government Printer.

Pajares, F. (1992). Teachers' beliefs and educational research: Cleaning up a mess construct. Review of Educational Research, 62, 307-332. http://dx.doi.org/10.3102/00346543062003307

Pendergast, D., Garvis, S., \& Keogh, J. L. (2011). Pre-service teachers' self-efficacy beliefs: An insight into making teachers. Australian Journal of Teacher Education, 36(12), 46-57. http://dx.doi.org/10.14221/ajte.2011v36n12.6

Report on the national commission on education. (1993). Republic of Botswana, Government Printer, Gaborone, Botswana.

Ross, J. A. (1992). Teacher efficacy and the effects of coaching on student achievement. Canadian Journal of Education, 17(1), 51-65. http://dx.doi.org/10.2307/1495395 
Ross, J. B., Cousins, J. B., \& Gadalla. (1996). Within-teacher predictors of teacher efficacy. Teaching \& Teacher Education, 12(4), 385-400. http://dx.doi.org/10.1016/0742-051X(95)00046-M

Shaughnessy, M. (2004). An interview with Anita Woolfolk: The educational psychology of teacher efficacy. Educational Psychology Review, 16(2), 153-176. http://dx.doi.org/10.1023/B:EDPR.0000026711.15152.1f

Stein, M. K., \& Wang, M. C. (1988). Teacher development and school improvement: The process of teacher change. Teaching and Teacher Education, 4, 171-187. http://dx.doi.org/10.1016/0742-051X(88)90016-9

Tschannen-Moran, M. T., Hoy, W. A., \& Hoy, W. K. (1998). Teacher efficacy: Its meaning and measure. Review of Educational Research, 68(2), 202-248. http://dx.doi.org/10.3102/00346543068002202

Tschannen-Moran, M., \& Woolfolk Hoy, A. E. (2001). Teacher efficacy: Capturing an elusive construct. Teaching and Teacher Education, 17, 783-805. http://dx.doi.org/10.1016/S0742-051X(01)00036-1

Woolfolk, A. E., \& Hoy, W. K. (1990). Prospective teachers' sense of efficacy and beliefs about control. Journal of Educational Psychology, 82, 81-91.http://dx.doi.org/10.1037/0022-0663.82.1.81

\section{Copyrights}

Copyright for this article is retained by the author(s), with first publication rights granted to the journal.

This is an open-access article distributed under the terms and conditions of the Creative Commons Attribution license (http://creativecommons.org/licenses/by/3.0/). 